\title{
THE PRICE IS WRONG: CAUSES AND CONSEQUENCES OF ETHICAL RESTRAINT OF TRADE
}

\author{
Thomas C. Leonard ${ }^{\circ}$
}

\section{Introduction}

A market transaction requires consensual exchange of goods, services or promises. Consent, unanimous consent, is the key. Both buyer and seller must consent to the deal; both must be empowered to veto the exchange. Transactions that are not fully voluntary in this sense, such as those within firms, which involve an authority relationship, or those, such as forced labor, which coerce, are not market transactions (McMillan 2002: 5-6) $\mathbf{1}$. The modern case for consensual exchange is both liberal and Paretian. The freedom to chose meets liberal goals because it is an exercise of personal autonomy, valuable for its own sake. Consent also promotes, instrumentally, the goals of the Paretian, as voluntary trade is more likely than coercion to promote the well being of the transactors ${ }^{2}$. Given these advantages, under what circumstances should voluntary exchange between consenting adults be ethically restrained?

A venerable critique of free markets says that restraint of trade is justified when that trade wrongly commodifies, when, that is, a market transaction occurs when it should not. Critics of commodification say that market exchange is wrong because it morally corrupts, is wrongly coerces, and it crowds out ethically

\footnotetext{
Thomas (Tim) Leonard is Lecturer in the Department of Economics, Fisher Hall, Princeton University, Princeton, NJ 08544. E-mail: tleonard@princeton.edu.

1 The "free" in free markets thus means "uncoerced". "Free" does not mean that a market trader is at liberty to do anything she likes. All functionning markets have rules, such as those pertaining to property and contract, which constrain the trader's scope of action.

2 In settings where one person's well-being is affected by another person's choices, the Paretian goal of mutual gains from trade can be at odds with the liberal goal of promoting autonomy by reducing coercion. In Sen's (1970) famous Lewd-and-Prude example, the outcome that maximizes joint welfare simultaneously reduces freedom, and the outcome that is freely chosen results in sub-optimal welfare.
}

Volume 14, numéro 4, Décembre 2004, pp. . 
superior means -such as altruistic giving- of allocating scarce goods. Karl Marx saw corruption, coercion and the displacement of more traditional forms of social organization as endemic to all forms of capitalist trade. His ringing lines from the Manifesto of the Communist Party are still the best statement of this critique and its ethos:

"The bourgeoisie ... has left remaining no other nexus between man and man than naked self interest, than callous "cash payment". It has drowned the most heavenly ecstasies of religious fervour, of chivalrous enthusiasm, of philistine sentimentalism in the icy water of egotistical calculation. It has resolved personal worth into exchange value . . . and has set up that single, unconscionable freedom - Free Trade . . . . It has converted the physician, the priest, the poet, the man of science, into its paid wage-laborers. [It] has torn away from the family its sentimental veil and reduced the family relation to a mere money relation $\mathbf{3}$.

Modern proponents of the ethical restraint of trade, such as Margaret Jane Radin ${ }^{\mathbf{4}}$, draw up a narrower indictment. Radin focuses upon blood, body parts, sex, and other goods seen to be so bound up with personhood that theire commodification has unavoidable moral consequences. This paper examines the ethical and economic issues that arise when we, on grounds of commodification, morally condemn and legally restrain trade.

\section{Inalienability: the price is wrong}

U.S. law bans the transfer, sale or gift, of many goods, e.g., certain drugs, votes, the products of endangered animals. This essay considers "gift but not sale" goods, goods critics say may be donated but not sold, such as blood or organs. Critics of commodification do not object to ownership or to transfer of "gift but not sale goods" 5 . The case against commodification and for the ethical restraint of trade, is founded upon the idea that the price is wrong. It is the compensation (or consideration, or payment, or quid pro quo) that market exchange entails, critics say, that makes for commodification and its moral costs.

3 Tucker-1978, pp. 475-76.

4 Radin-1996.

5 In legal terms, the argument is that individuals have delimited property rights. persons have ownership - the legal right to exclude others from using one's property without one's consent - in intimate or bodily goods, and they have the legal right to alienate (read: transfer) owned intimate goods, nut persons may not legally alienate intimate goods for monetary or other consideration. 


\section{What makes the price wrong?}

Commerce, like all human action, has a moral dimension. Everyday language reflects the idea that not everything should be for sale: "that judge is bought;" "you sold out;" "he would sell his own grandmother." Michael Sandel ${ }^{6}$, a distinguished moral philosopher, entitles his Tanner Lectures What Money Can't Buy. There are things that money can't buy - love, friendship and respect among them - but these are not Sandel's brief, which is to argue what money shouldn't buy.

Sandel begins with a High-Table anecdote about a hapless upper class twit who offers a five-pound gratuity to his tutor, a distinguished Marxist historian ${ }^{7}$. Sandel contrasts the don's indignation with Adam Smith's enthusiasm for student compensation of university teachers. In The Wealth of Nation, Smith argued that if students paid their proffesors directly, better teachers (measured by greater enrollments) would be better paid. Sandel offers the tipping-the-don story, along with the practice of book stores selling placement to publishers, as instances of "the extension of markets and of market-oriented thinking into spheres of life once thought to lie beyond their reach"8.

Sandel is surely right that markets and market thinking have extended their reach. But the question is whether this is good or bad. Does the extension of markets make college teaching and books better or worse?

Sandel assumes that markets cause the sale of shelf space to blockbusters, brand-name authors. But this practice is better seen as the product of a missing market. What is missing is information regarding a book's quality. Books, like films and wine and modern art, are "experience goods," buyers can't easily judge quality by mere examination. This is why readers traditionally resort to critics and to brand-name authors. Many readers would like to know what's good rather than what's popular, but this information is costly to obtain, so readers avert to what they know, which contributes to the blockbuster phenomenon.

Today, however, there exists a developing market in information about book quality. Book buyers at on-line vendors will be familiar with "recommender systems," software that compares information about a consumer's taste in books with that of other like-minded readers, to generate recommendations about what's good, books of which the reader would likely have been unaware. I hazard a prediction that, as recommender systems help address the experience-goods problem, unknown, highquality books will increasing gain at the expense of well-known, low-quality books.

On-line book selling, another market extension, has also greatly expanded the inventory of used books available to book lovers. My library is peppered with volumes from booksellers in places I have never visited, and never will. This market extension is also, of course, a boon for the book sellers, especially for 6 Sandel-1998.

7 The practice of tipping also involves status, and thus goes beyond the matter of performance-based compensation. Professors are compensated. And students (or taxpayers) pay tuition. The don is offended because he does not regard his vocational station as one that receives tips - dons give tips, they do not receive them. Adam Smith, for his part, famously regarded philosophers and street porters as equal.

8 Sandel-1998, p.93. 
small, literary bookshops. Sandel imagined markets destroying the Blackwells of the world, when, in fact, markets may save them.

Sandel moves to firmer ground when he considers goods more obviously implicated in personhood, such as prostitution and organ selling. Sandel's argument is twofold: such markets morally corrupt - "certain moral and civic goods are diminished or corrupted if bought and sold for money"9 - and such markets also wrongly coerce sellers $\mathbf{1 0}$.

I grant that trade in some goods is "intrinsically degrading," that prostitution, for example, can corrupt the "moral worth of human sexuality"11. I also grant Sandel's claim that moral corruption does not depend upon "tainted consent." Prostitution can be morally degrading even when prostitutes are the socioeconomic equals (or betters) of their clients and freely choose their work. While I doubt that commercial sex exhausts the category of practices that corrupt the worth of human sexuality, I grant that these costs are real. But to complete a moral argument, we need to compare the moral costs of commercial sex with the moral costs of the alternative, a ban on commercial sex and other commodified goods. This comparison is undertaken in Section 10. In the next section I consider Sandel's charge that commodification coerces.

\section{Can voluntary trade coerce?}

Market transactions are consensual. How, then, does a market transaction coerce? A peasant consents when he sells a kidney to feed his starving family, says Sandel, "but his agreement is not truly voluntary." Why not? Because "he is coerced, in effect, by the necessity of his situation," by the absence of "fair background conditions"12. Similarly, says Sandel, the soldier in the volunteer army is no less coerced than the conscript; the state compels the conscript and "economic necessity" compels the volunteer enlistee $\mathbf{1 3}^{\mathbf{3}}$.

Sandel's metaphorical claim that necessity coerces is misleading. The size of one's opportunity set and the freedom to choose among the alternatives in it, however limited, are distinct things. So, while it is tempting to conflate freedom of choice with the size of the choice set, since necessity and coercion both work to delimit alternatives, necessity and coercion reduce alternatives in ethically distinct ways.

9 Ibid, p. 94.

10 This phrasing notwithstanding, I don't believe that Sandel intends to object to money price per se. Critics of commodification ordinarily object to any form of payment, whether denominated in money or goods. A money price is especially salient, peharps, because it signals both the tems of trade and the fact of trade. But money is not the problem for Sandel and like critics, trade is.

11 Sandel-1998, p. 95.

12 Sandel-1998, p. 94.

13 Sandel-1998, p. 111. 
The mugger's offer - your money or your life - is no offer at all. It coerces. The mugger reduces his victim's alternatives by taking from the victim a legal entitlement - safety in one's person - and selling back to the victim. The organ buyer's offer, in contrast, expands the set of alternatives available to the organ seller. The buyer, unlike the mugger, does not create the other party's necessity.

Similarly, the gravely ill patients awaiting organ transplant do not cause the poverty that makes some organ sellers necessitous. The U.S. Army does not impoverish young men and women in order ot increase its pool of potential recruits. One can lament, rightly, the poverty that gives rise to necessity. But this is an objection to poverty, not to coecicion. What is unfair should not be conflated with what is unfree.

To insist that necessity and coercion reduce alternatives in ethically distinct ways does not to deny that, at the limit, desperate persons lack meaningful choices. The rescuer who sells water at an extortionate price to the wealthy man dying of thirst may not create the victim's duress, but he exploits his monopoly power, which arises from the thirsty man's necessity. So, though the buyer consents, and is unambiguously better off for having purchased the water, our intuition suggests that consent is not sufficient here to justify the extortionate terms of trade. The economist Ravi Kanbur ${ }^{\mathbf{1 4}}$, in his discussion of why "obnoxious markets" promote "discomfort, distrust, even outrage," identifies as causes, (1) highly unequal market relations, and (2) extremity of outcome. Both aspects characterize the thirsty-man story. The "rescuer" has the thirsty woman at his mercy, and the alternative to purchase is death.

And yet even here, the problem is not with consent, it is with the background conditions, the lack of alternatives that necessity entails. It would be absurd to ban trade, to prohibit the rescuer from selling the water on (the mistaken) grounds that the buyer was being coerced. We might wish to regulate the terms of trade. Suspend property rights in such emergencies; allow the thirsty woman to "privately take" the rescuer's water, and compensate the rescuer for the taking. This would be, in effect, price regulation of monopoly.

It would be even more efficacious to address the cause rather than treat the symptom. Change the background conditions that foster the monopoly, that is, to provide incentives that promote more competition among rescue services. Competition has the moral virtue of expanding alternatives to buyers (and sellers), which reduces the likelihood of necessity and exploitation

Not all background conditions are easily changed. Poverty is, of course, a vastly more intractable problem than the provision of rescue services. Still, the point remains: when one mistakes bad alternatives for coercion, one can be misled into thinking, as with coercion proper, that the best response is to ban trade. But trade bans only shrink further the few alternatives left to the necessitous $\mathbf{1 5}$.

14 Kambur-2000, p.39

15 Margaret Jane Radin (1996) recognizes this problem, calling in the "double mind". 


\section{Do price incentives crowd-out altruism?}

Richard Titmuss's influential The Gift Relationship: From Human Blood to Social Policy marked the culmination of his decade-long antagonism toward the free-market economists of London's Institute of Economic Affairs (IEA), who earned Titmuss's ire when they proposed that state-provided medical services should be priced in markets $\mathbf{1 6}$. The Gift Relationship was most influential for its central thesis that price incentives crowd out altruistic donations so that price, contrary to the Law of Supply, decreases rather than increases the supply of blood. Titmuss also argued that price incentives would reduce blood quality, in the form of a higher rate of transfusion-transmitted diseases (notably, serum hepatitis). The sale of blood, for Titmuss, reduced the quantity and the quality of the blood supply, this while also diminishing social cohesion by undermining altruism more generally.

Take the most influential claim first, that price reduces rather than increases the blood supply. Titmuss's early critics among economists, notably Kenneth Arrow $\mathbf{1 7}$ and Robert Solow $\mathbf{1 8}$, were not all free-marketeers of the IEA variety. Politically left-of-center, and not uncomfortable with an expansive state role in the economy, Arrow nonetheless took strong issue with Titmuss's central claim. The economist, Arrow explained, sees the opportunity for payment, when added to a donor-only regime, as an expansion of a blood supplier's alternatives. Those who wish to give may still give, and that right is in no way impeded by the right of others to sell. The additional supply induced by payment is socially beneficial. After all, if the blood supply produced under a donor-only regime is good, why isn't more better?

Titmuss, of course, disagreed, "As this study has shown comparatively, private market systems in the United States and other countries . . . deprive men of their freedom to choose to give or not to give"19. For Titmuss, the option to sell, in effect, removes the choice to make a gift. The expansion of one's alternatives is thus illusory, because the sales crowd out gifts, via a kind of Gresham's law. For Titmuss, as for subsequent defenders of the crowding-out thesis, such as Peter Singer ${ }^{\mathbf{2 0}}$, price has the adverse consequence of reducing supply by coercing altruists who wish to give $2 \mathbf{1}$.

Arrow and other early critics noted that Titmuss produced very little empirical evidence for the key claim that the right to sell impaired the right to give. Titmuss clearly meant to juxtapose the donor-model regime of the United Kingdom, with the U.S. model of payment and donation. But Titmuss's data don't 16 See, for example, Cooper and Cuyler (1968) The Price of Blood. For an interesting account of the origins of Titmuss's book in his debate with the IEA, see Fontaine 2002.

17 Arrow-1972.

18 Solow-1971.

19 Titmuss-1971, p. 239.

20 singer-1973.

${ }^{21}$ In this sense, Titmuss avoids Sandel' s conflation of what is unfair with what is unfree. Titmussian donors are coerced not because they are necessitous, but because Titmuss sees sales as shrinking rather than expanding the set of alternatives available to blood suppliers. 
even permit an apples-and-apples comparison of the U.K. and U.S., and even if they had, and had showed a greater supply in the U.K., this would hardly be sufficient to establish that the cause of the hypothetically greater supply was the absence of compensation. It could be, as Arrow noted, that the causality ran the other way, that the U.S., for whatever reason, was less altruistic, and adopted commercial supply to increase the blood supply 22 . Commercial blood would then be a consequence of insufficient altruism rather than a cause.

Titmuss is also unclear on the theoretical mechanism by which price crowds out altruistic supply. Titmuss did not argue that donors would opt to become sellers, for he argued that total supply would fall, and (see below) he saw suppliers as more or less fixed types - either altruists or mercenaries - whose type was revealed by whether or not they accepted payment. So why does altruistic supply fall with the advent of compensation?

Do Titmussian donors stop donating upon learning that others might be accepting payment - the knowledge that someone, somewhere is accepting payment for blood suffices to induce these donors to stop donating? Or do Titmussian donors stop donating when presented with the threat that they themselves will be obligated to accept unwanted payment? Or is the source of discomfort the fear that others will know that one has accepted compensation? Does crowding-out come from: (1) payment to others, (2) payment to oneself, or (3) the social stigma of payment to oneself? 23

Each of these potential explanations runs into difficulties. Titmuss would not regard as altruists members of category (3), since these people are the sort who would sell blood, even if they don't wish to be known as such. They want to avoid disapproval, not to avoid behavior that merits disapproval. As there is no compulsion to accept payment, category (2) can also be ruled out, at least insofar as these donors don't care about reputation. If, however, reputation matters, and category (2) members thus want to signal their altruism - "I'm not the sort who sells blood," - there must be a low-cost means for these donors to distinguish themselves from sellers, such as a blood-donation pin not awarded to sellers $\mathbf{2 4}$.

Category (1) donors are more likely to be the model Titmuss had in mind; indeed they may well be offended by commercial blood for the same reasons adduced by critics of commodification. The trouble here is that even when the law proscribes payment to persons who supply blood, blood is, eventually, sold.

22 Arrow-1972, pp.350-351

23 Duty is another possible motive, but it's hard to conceive of Titmussian altruist, who stop donating with the advent of sales, as those motivated by a Kantian sense of duty. Kantian agents motivated by obligation seem unlikely to treat their obligation as conditional on the behavior of others.

24 Signaling complicates the analysis in a way we lack space to pursue. If crowding out comes principally from the stigma of publicly accepting compensation, that is, from category (3) sellers and not from category (2) donors, then payment could be arranged discreetly, so that sellers are indistinguishable from donors. The idea is analogous to the proposal that food-stamps recipients should not be obliged to feel stigma when using food stamps to transact in the check-out line at the grocery, and shoudl instead be given governmentaccount debit cards which are indistinguishable from ordinary debit and credit cards. 
In the United States, for example, the Red Cross sells blood - whole blood and blood products, such as plasma - to hospitals, for-profit distributors and other buyers, thevery blood it requires individuals to give freely. Distributors, in turn, sell to plasma consumers, such as pharmaceutical companies; hospitals sell whole blood to patients requiring transfusions 25 . In the post-AIDS era, a unit of blood sells for \$150-200. The business of collecting blood and selling it provides the bulk of the American Red Cross's income, and constitutes a significantly larger enterprise than its disaster-relief services. And yet, the fact that most donated blood is sold (to say nothing of wholly commercial blood) does not deter the many American volunteers.

It could be that blood donors are unaware that the Red Cross sells their blood. Or it could be that blood donors are fully aware that their donated blood is sold, and regard this as an acceptable way to fund the Red Cross's disaster relief work ${ }^{26}$. The Red Cross's official reply seems to support the first hypothesis. It denies that it sells blood, preferring to characterize the payment it receives from blood buyers as "cost recovery." This is a distinction without a difference, ethical or economic. The Red Cross does not offer "cost-recovery" to donors. And the prices the Red Cross charges exceed its costs, in order to create a "reserve," which, in ordinary language, would be termed a profit. The difference between price and "cost-recovery" is, moreover, a distinction that Titmuss himself would emphatically deny - payment is payment.

The fact that a market in blood does not influence at least some donors to withdraw is not sufficient to disprove Titmuss's main hypothesis. It could be that the Titmussian altruists have already exited owing to commercial blood, and that this supply loss exceeds any supply gains from payment to suppliers. But it does suggest that any crowding-out effect is, at a minimum, less than total. A large class of donors apparently can live with other donors, and blood procurers, being paid. A second point is that those who advocate for gifts tend to forget the demand side. Even when sales bans successfully compel suppliers to make gifts, they ordinarily do not compel that recipients receive the gift. In fact, what we donate - blood, organs, used clothing - ordinarily does not result in a gift to beneficiary. On the contrary, "beneficiaries" commonly pay for blood and organs and used clothes, and they pay prices higher than what would obtain were supply not legally restricted. Why? Because sales bans necessitate intermediaries. Organizations such as blood and organ banks are legally empowered to allocate vital goods when a market may not. Donors are not paid but intermediaries are.

25 That most patients have health insurance does not change the fact of the sale, only the identity of the payer.

26 The used-closing business works in similar fashion. Used clothes are donated to charitable groups, who then sell the used clothes (or contract with vendors who sell the clothes) to markets in Africa and Asia. 


\section{Do price incentives reduce blood quality?}

Economists have found Titmuss's argument that paid blood leads to adverse selection more persuasive than his more famous claim that paid blood crowds out altruistic donation.

Because blood quality is costly for procurers to judge, payment will tend to attract the very higher-risk donors procurers wish to avoid - adverse selection. The informational asymmetry is less dangerous with blood donors, who, being altruistic, will not knowingly supply tainted blood. Titmuss's adverse selection theory is clearer and his evidence is stronger than that for the crowding-out claim.

But Titmuss's adverse-selection argument doesn't demonstrate, by itself, that a regime of blood sales must be inferior to a regime of blood donation. Banning sales to avoid adverse selection is but one of many means to reduce the risk of tainted blood. Another interlocutor of Titmuss's, Rueben Kessel27, argued that tainted blood arose from lax standards of legal liability. Blood banks were legally obliged only to observe "good practices" with respect to blood safety, effectively what they already were already doing. Kessel argued that if blood banks were made strictly liable for the cost of any tainted blood they supplied, they would have appropriate incentives, then lacking, to screen their blood supply more carefully. Titmuss, however, opposed strict liability, which he saw (correctly) as another form of pricing, the pricing of expected harms..

Abstracting from quantity effects, altruism will be a better option than strict legal liability only insofar as donors have good information about their blood quality. This assumption was perhaps reasonable for hepatitis, the chief worry in the 1960s. It proved tragically costly when, beginning in the 1980s, HIV entered the blood supply, from well-intended donors, not yet afflicted by AIDS, and thus unaware they were transmitting a deadly disease.

\section{Titmuss updated by economists}

Titmuss's argument against price is more consequentialist than that of others who oppose commodification, perhaps reflecting The Gift Relationship's origins in social science, not moral philosophy. Sandel argues that commodification is morally wrong in and of itself. Titmuss, in contrast, emphasized what he saw as the adverse consequences of price, especially the diminishment of altruistic supply, the undermining of the opportunity to make gifts. Although (or perhaps because) Titmuss supplied very little evidence in support of the crowding-out hypothesis, his framework has attracted the recent interest of some behavioral economists, notably Bruno Frey and his co-authors 28 .

\footnotetext{
27 Kessel-1973.

28 Frey-1997, Frey/Oberholzer-Gee-1997.
} 
Frey and his co-authors make use of social psychology and locate the crowding-out result in the interactive effects of what they call extrinsic and intrinsic motivation. Extrinsic motives refer to activities pursued for some end, such as consumption. But utility comes also from intrinsic sources, which refers to the pursuit of activities, such as civic duty, that offer no apparent reward, except for the activity itself $\mathbf{2 9}$. A person paid to do something he is intrinsically motivated to do, will suffer utility losses that may well exceed the utility gains provided by the greater consumption payment enables. Thus can price incentives crowd-out altruistic behavior.

Frey and co-authors improve on Titmuss in several ways. First, they gather some very interesting and compelling empirical evidence of crowding-out effects. Their evidence must weighed against a much larger body of evidence that supply curves are upward sloping, but at least they present some direct evidence. Second, Frey, unlike Titmuss, does not think the possibility of crowding-out supports or, still less, constitutes an indictment of market pricing in the large. To the contrary, Frey and co-authors claim only that in settings where intrinsic motives are present, crowding-out by price may (or may not) occur. Third, Frey and coauthors allow for mixed motive; both extrinsic and intrinsic elements appear in the agent's utility function $\mathbf{3 0}$.

\section{Does payment determine motive, and can motives be}

\section{mixed?}

Titmuss reserved the title of "altruist" for a extremely select group. Only those blood suppliers who received no compensation whatever, whether money, payments in kind (meal or transportation money, e.g.) or the promise of blood should they need it in the future, were deemed altruistic by Titmuss. Blood suppliers who received money, goods or promises of future payment in blood are, for Titmuss, sellers and not donors 31. Two things follow. One is the fact that altruism, as defined by Titmuss, is rare. Titmussian altruists contributed only nine percent of blood supplied in the United States 32 . Even in the U.K., where commercial blood was banned, only six percent of the eligible population donated

29 Frey-1997, p. 13.

30 Frey and co-authors follow Titmuss, however, in keeping selling and giving different, making them the products of two distinct, separable sources of motivation, extrinsic and intrisic, respectively. Thus, like Titmuss, they assume without explanation that people regard selling and giving the same good - even when it has identical consequences - as belonging to fundamentally separate categories. This critique is due to Paul Seabright (2002), who offers an interesting theoritical account of why giving and selling the same good are considered to be categorically different activities.

31 Even donors who specify a recipient other than themselves, i.e do not give to anonymous recipients, do not qualify as fully altruistic in Titmuss' s view.

32 Titmuss-1971, p. 94. 
blood.

Second, for Titmuss, the presence or absence of compensation determines the nature of the act, gift or sale, and it also determines the motive for the act, altruistic or mercenary, respectively. If one receives no payment, the act is a gift, and, Titmuss concludes thereby, the motivation is wholly altruistic. If one receives any payment whatever - money, good, promise - the act is a sale, and, he concludes thereby, the motivation is wholly mercenary.

All reduces in Titmuss to a crude gift-or-sale, mercenary-or-altruist dichotmomizing. This scheme rules out both mixed motive and motives other than altruism or financial gain. First, the Titmussian agent is either a pure altruist or a pure mercenary, as determined by the absence or presence of compensation. This rules out non-mercenary motives other than altruism.

But, as David Archard points out regarding sex, "sex may be exchanged with monetary payment from motives of moral duty, love, revenge, anger, indifference, lust, fear, hatred even"33. Second, even if we are prepared to assume, with Titmuss, that altruism and financial gain exhaust all possible motives, Titmuss also rules out the prospect that both motives may be present in one person. The person who wishes to work for the benefit of others and to earn a living doing it, for example, is, for Titmuss, a mercenary. And, the blood donor who felt some subtle social pressure to give, is, for Titmuss, an altruist through and through.

There are, however, important social practices, including charitable giving, that seem to possess elements of both altruism and exchange, a consideration of which helps illustrate the rigidity and narrowness of Titmuss's either-altruist-ormercenary construction.

\section{Is the gift relationship always exchange-free?}

Titmuss argued, as suggested by the title of his book, that altruistic blood donors should be seen as a making a gift. The use of the term "gift" is not accidental. Nor is it incidental. It is, in fact, central to Titmuss's larger critique of capitalist market relations. Titmuss, known as the "philosopher" of the British Welfare State, intended his critique of commercial blood to be a kind of synecdoche for his late-Fabian view that the state and not markets should allocate vital goods and services. This view is evident in an earlier paper, where Titmuss proposed that:

The grant, or the gift, or the unilateral transfer - whether it takes the form of cash, time, energy, satisfaction, blood, or even life itself - is the distinguishing mark of the social (read: socialistic) ... just as exchange or bilateral transfer is the market of the economic 34 .

Titmuss wanted gift relations to serve as a foil to market relations, not merely to juxtapose the high-minded motives of the altruist, with the self-seeking of the 33 Archard-1998, p. 367.

34 Cited in Fontaine-2002, p. 412. 
market transactor. The distinction Titmuss makes between gifts and exchanges also serves, for him, to philosophically demarcate socialism and capitalism, respectively.

Set aside the notion that socialism is best characterized by the charitable impulse, and consider Titmuss's identification of altruism with gift giving. The Titmussian blood donor wants and expects nothing in return. But if altruists only make gifts, it is not true that all gifts are made only by altruists in Titmuss's strict sense.

Gift giving, in fact, is quite often characterized by the want or expectation of something in return. It is a staple of the anthropological literature on gift giving, that gifts are often characterized by exchange. In some cultures, potential recipients dread gifts, precisely because the receipt of a gift imposes costly reciprocal obligations. In the United States, the demands of gift-reciprocity need not be onerous, of course, but it is very common for social rules to impose reciprocal obligations upon gift recipients 35 .

In fact, some scholars of giving treat the gift relationship not as the absence of exchange, but as a species of exchange - a subtle, complex, and refined social mechanism designed (or evolved) to enable trade in social settings where it is vulgar (or otherwise inappropriate) to signal the fact, still less the terms, of trade $\mathbf{3 6}$. One needn't look far for contemporary examples. Consider elite philanthropy.

Charitable gifts that are not anonymous come with recognition, and often a tax break, too. New York high society is built around parties that publicly celebrate the benefactors of leading cultural institutions. Non-anonymous donations to American private Universities also come with a quid pro quo eponymic recognition, celebratory dinners, and perhaps even special consideration for the admissions applications of the benefactor's progeny. The humblest donation will land the donor's name in the alumni magazine, with eponymic quid pro quos that increase with the size of the gift - a plaque, a professorial chair, a named building, a named professional school, up to the University's name itself. University "development" offices publish what amount to price schedules. These familiar practices do not commodify so much as they ratify the exchange already present in transactions that are ordinarily represented as giftgiving.

None of this impugns the motives of the philanthropic. It simply recognizes what Titmuss does not, that gift giving can arise from mixed motive, that public recognition and approbation are desirable goods even to persons motivated primarily by a desire to benefit others 37 . Many blood donors opt to 35 When acquaintances invite you to dinner, do you feel an obligation to reciprocate? And when you arrive at their house, do you feel an obligation to present them with wine or flowers? You will likely to refer, unless you are uncouth as the twit in Sandel's anecdote, to the wine as "payment for the meal." But the convention that gifts of dinner are to be reciprocated is powerful, enough that express attempts to contravene it - invitation that request "no gifts," for example - are ordinarily ignored.

36 See, for example, Davis (200).

37 Or, as argued By Seabright (2002), and Glazer and Konrad (1996), non-anonymous gift giving offers a socially sanctionned way of signalling wealth, (say, where conspicuous 
display the donor pins that signal their virtue. Anonymous gifts are different, because anonymity precludes recognition and approbation. But anonymous giving is, tellingly, the rare exception. Less than one percent of charitable gifts are anonymous, a measure, perhaps, of the value that donors attach to recognition and approbation $\mathbf{3 8}$.

The difficulty for Titmuss's scheme is clear. Either non-anonymous philanthropy is rightly seen as a gift, but one partly motivated by exchange considerations, which violates Titmuss's either-mercenary-or-altruist taxonomy. Or, consistent with the narrow definition of altruism in The Gift Relationship, nonanonymous philanthropy should be regarded as mercenary - there is, after all, compensation for benefactors, and their gift is made not to strangers but to a designated beneficiary. Moreover, if Titmuss maintains his narrow definition of altruism, then he must regard non-anonymous philanthropy as mercenary, and consistency would require him to argue that non-anonymous philanthropy should be banned, on grounds that it crowds out the "untainted" altruism of the donors who make anonymous gifts.

\section{The moral cost of restrictions on trade}

Moral condemnation of commodified trade does not entail legal restriction of that trade. Some critics of commodification - Radin is notable in this regard - are careful to explore the possibility that legal cures may be worse than market diseases. Sandel recognizes that "prohibition may carry moral and practical costs that outweigh the good of preventing the practice" (96), but he declines to consider these moral and practical costs. This is an unfortunate omission, for, to complete a moral argument, the moral costs of trade must be weighed against the moral costs of trade bans.

This section takes up three examples of the moral costs of legal trade restrictions. Trade prevented is the first moral cost - in the form of the harms visited on patients denied life-saving organ transplantation. The second moral cost is of trade that is not prevented - the harms visited on traders who assume the special risks created by illegal markets. The third moral cost occurs when markets do not mediate exchange, legal or illegal. Titmuss notwithstanding, the gift relationship is not the only alternative to markets. Historically, when price does not mediate exchange, social status, or authority does.

The most important idea is that buyers' willingness to pay and sellers' willingness to accept are not affected by laws that regulate price. A trade ban, which effectively sets price to zero, serves only to create to a shortage in the legal marketthe difference between the number of sellers willing to accept no compensation, and the number of buyers willing to pay no compensation. In 2002, 3,400 U.S. kidney patients died of renal failure while on the waiting list for a kidney transplant, and another 900 became too ill to be eligible for transplantation 39. And because demand (as measured by all wait-list patients) for kidneys is increasing more rapidly than consumption is deemed vulgar), as well as ones's generosity.

38 See the evidence reported in Glazer and Konrad (1996, p.1021)

39 Roth/al.-2004, p. 458. 
supply, the annual toll can be expected to rise.

Most observers agree that, were compensation of kidney donors legal, the shortage would vanish. In a real sense, then, the trade ban on kidneys results in thousands of preventable deaths annually. It can be argued that the human toll of this trade ban is justified by the moral corruption and exploitation of sellers prevented, and by the imprudent choices (by potential sellers) avoided. But this argument must be made, and opponents of commodification (Radin, again, excepted), generally do not consider the moral costs of trade bans.

Even if one were to decide that thousands of preventable deaths per year were an acceptable price to pay to avoid moral corruption, exploitation, and imprudent choices, it is well to remember that corruption, exploitation and imprudence are not abolished by laws that ban priced trade. On the contrary, a legally enforced shortage drives buyers and sellers underground, into illegal markets. And illegal markets are places where corruption, exploitation and imprudence are made worse, not better.

Consider exploitation. Prostitutes in jurisdictions where sexual services may legally be sold, such as Amsterdam or Nevada, do not retain pimps. A legal sex trade, like the legal drug trade (cigarettes, e.g.), is ordinarily much freer of violence against sellers than is the illegal equivalent. Pimping, and the violence it visits upon prostitutes is the product of the law that bans prostitution.

Illegal markets also increase surgical and medical risks to those who undergo nephrectomies. The mortality risk for a nephrectomy in developed countries, where nearly all surgeries are legal (i.e., for donors not sellers), is lower than $1 / 1,000$, or lower $\mathbf{4} \mathbf{0}$. Kidney donors also seem to suffer no adverse long-term health consequences on average ${ }^{\mathbf{4 1}}$. Critics of kidney sales instance evidence that Indians who sold a kidney subsequently regret their choices; 79 percent of these respondents advised others not to do so $\mathbf{4 2}$

But it is well to remember that these impoverished sellers were operating in an illegal market. Because of this, the prices sellers received (about \$1000) were likely more exploitive than what they would have earned in a legal market, and, their surgical care (and pre- and post-operative care) care was also likely dangerous and substandard. In other contexts, the positive effect of legality upon safety is routinely cited. One of the strongest arguments for legal abortion, for example, is that legal abortion is a safe, low-risk procedure. "Back-alley" abortions, that is, abortion services where the law bans them, greatly increase mortality and morbidity risks to women.

A final moral cost of banning trade concerns the harms created by nonprice means of goods allocation. Even if the price is wrong, it doesn't follow that non-price means will be morally better. Elizabeth Anderson, who has elsewhere

40 Becker/Elias-2003, p. 10.

41 Najarian/al.-1992.

42 Goyal/al.-2002. 
argued against commodification, offers the case of bankruptcy. Until the $18^{\text {th }}$ century, obligation or debt to others was measured not by the nature of the good received (the value of credit), but by the relative social status of the transactors. Capitalism, Anderson argues, "enabled masses of people, for the first time, to obtain credit without being subject to moral opprobrium or social subordination." By substituting exchange determined by price for "aristocratic honor," capitalism "demoraliz[ed] the conditions of debt and insolvency . . . and dramatically increased the freedom, equality, and prosperity of millions of people" $\mathbf{4 3}$.

Though he would not have approved, this is phenomenon is part of what Marx referred to when he characterized capitalism as having "put an end to all feudal, patriarchal, idyllic relations," having "pitilessly torn asunder the motley feudal ties that bound man to his "natural superiors" $\mathbf{4 4}$.

\section{Should everything be for sale?}

A liberal market order, founded upon consent, places a high value on the rights of persons to alienate, for money or for nothing, what they own. But even the liberal case for alienability is not unlimited. It will not, for example, sanction contractual slavery, which, as Archard $\mathbf{4 5}$ argues, removes the very conditions that make freedom valuable to a person. It also will not allow the sale of political and judicial decisions. Functioning markets require rules, notably laws of property and contract, and their enforcement. A functioning system of property rights cannot be sustained with the corruption that arises when the decisions of politicians, judges and police are alienable. In this sense, a price system must be incomplete; the legal structures upon which a price system rests cannot themselves be priced.

While consent does not require universal alienability, it does make the scope for free trade, quite broad. Michael Sandel summarized his Tanner Lectures with a broadside directed at "libertarian philosophers and political theorists, rational choice economists, and adherents of the "law and economics' movement." He also indicts as co-conspirators the "liberal consent theorists" - those who think that "there's nothing wrong with commodification that fair terms of social cooperation cannot cure" - for failing to recognize that there are "dimensions of life that lie beyond consent" $\mathbf{4 6}$.

But how does Sandel propose to legitimately travel to the "dimensions beyond consent," if not via consensual means? The only way to get beyond consent without agreement is to coerce. And, by removing the bulwark of consent, Sandel invites the danger that such coercion will be illegitimate. This is what happened in mid-Victorian English political economy.

\footnotetext{
43 Anderson-2004.

44 Tucker-1978, p.475.

45 Archard-1998, p.364.

46 Sandel-1998, p.122.
} 
The $19^{\text {th }}$-century Romantic critics of capitalism, especially Thomas Carlyle and John Ruskin, attacked low factory wages, even as they publicly defended the violent plantation slavery that political economists, such as John Stuart Mill, opposed. Indeed, Carlyle's famous epithet for political economy - the dismal science - was not a swipe at Malthusian ideas, it was a racist double entendre directed at Mill and his allies in the anti-slavery movement $\mathbf{4 7}$.

To minimize overall coercion, Hayek argued, civil society must endure some coercion. Similarly, some limits upon the scope of what may be traded are required in order to secure the benefits of trade more generally. But these restrictions upon trade, unlike those that Sandel and other critics of commodification propose, should themselves be the product of consensual agreement.

47 The "dismal" in "dismal science" was meant by Carlyle as a reference to dark skin - part of his attempt to discredit Mill and the other liberal economists who opposed the brutal plantation slavery that Carlyle emphatically defended (Levy 2001). 


\section{References}

Anderson, E. (2004) "Ethical Assumptions of Economic Theory: Some Lessons from the History of Credit and Bankruptcy," in Carl-Henric Grenholm (ed.), Economics, Justice, and Welfare, special issue of Ethical Theory and Moral Practice.

Archard, D. (1998) A Review of Margaret Jane Radin, Contested Commodities: The Trouble with Trade in Sex, Children and Body Parts, Economics and Philosophy, Vol. 14, n², pp. 362-68.

Arrow, K. (1972) "Gifts and Exchanges," Philosophy and Public Affairs Vol. 1, n4, pp. 343-362

Becker, G. and J. Elias (2004) "Introducing Incentives into the Market for Live and Cadaveric Organ Donations." Mimeo. University of Chicago.

Davis, N. (2000) The Gift in Sixteenth Century France, Madison, WI: University of Wisconsin Press.

Fontaine, P. (2002) "Blood, Politics and Social Science: Richard Titmuss and the Institute of Economic Affairs, 1957-1973," Isis Vol. 93, n³, pp. 401-434.

Frey, B. (1997) Not Just for the Money: An Economic Theory of Personal Motivation. Cheltenham, UK: Edward Elgar.

Frey, B. and F. Oberholzer-Gee (1997) "The Cost of Price Incentives: An Empirical Analysis of Motivation Crowding-Out," American Economic Review Vol. 87, n4, pp.746-755.

Cooper, M.H. and A.J. Cuyler (1968) The Price of Blood. London: Institute of Economic Affairs.

Glazer, A. and K. Konrad (1996) "A Signaling Explanation for Private Charity," American Economic Review, Vol.86, n4, pp.1019-1028.

Goyal, M., R. Mehta, L. Schneiderman, and A. Sehgal (2002) "Economic and Health Consequences of Selling a Kidney in India." JAMA 288(13), pp. 589-1593.

Kanbur, R. (2002) "On Obnoxious Markets," in S. Cullenberg and P. Pattanaik (eds.) Globalization, Culture, and the Limits of the Market: Essays in Economics and Philosophy. New York: Oxford University Press, pp. 39-61.

Kesse1, R. (1974) "Transfused Blood, Serum Hepatitis and the Coase Theorem," Journal of Law and Economics, Vol.17, n², pp. 265-289.

Levy, D. (2001) "How The Dismal Science Got Its Name: Debating Racial Quackery," Journal of the History of Economic Thought Vol. 23, n²1, pp. 5-35.

McMillan, J. (2002) Reinventing the Bazaar: A Natural History of Markets. New York: W.W. Norton.

Najarian, J.S., B.M. Chavers, LE McHugh, and A.J. Matas (1992) "20 Years or More of Follow-up of Living Kidney Donors," Lancet n³40, pp. 807-10.

Radin, M. J. (1996) Contested Commodities: The Trouble with Trade in Sex, Children, Body Parts and Other Things. Cambridge, MA: Harvard University Press.

Roth, A. T. Sönmez and M. Ü. Unver (2004) "Kidney Exchange," Quarterly Journal of Economics Vol.119, n²2, pp. 457-488. 
Sandel, M. (1998) "What Money Can't Buy: The Moral Limits of Markets," Tanner Lectures on Human Values, Brasenose College, Oxford, May 11 and 12.

Seabright, P. (2002) "Blood, Bribes and the Crowding-Out of Altruism by Financial Incentives," Mimeo. Université de Toulouse.

Sen, A. (1970) "The Impossibility of a Paretian Liberal," Journal of Political Economy, Vol.78, n¹, pp. 152-57.

Singer, P. (1973) "Altruism and Commerce: A Defense of Titmuss against Arrow," Philosophy and Public Affairs Vol. 2, n³, pp. 312-320.

Solow, R. (1971) "Blood and Thunder." Yale Law Journal 80(2), pp. 170-83.

Titmuss, R. (1971) The Gift Relationship: From Human Blood to Social Policy. New York: Pantheon Books.

Tucker, R. (ed.) (1978) The Marx-Engels Reader $2^{\text {nd }}$ edition. New York: W.W. Norton. 